\title{
An Empirical Performance Evaluation of Universities Website
}

\author{
Sukhpuneet Kaur \\ Research Scholar \\ I.K.Gujral Punjab Technical \\ University, Kapurthala, India
}

\author{
Kulwant Kaur, $\mathrm{PhD}$ \\ School of Information \\ Technology \\ Apeejay Institute of \\ Management \\ Technical Campus, Jalandhar,
}

\author{
Parminder Kaur, PhD \\ Department of Computer \\ Science \\ Guru Nanak Dev University, \\ Amritsar, India
}

\begin{abstract}
The usability is acknowledged as an key eminence aspect of any website. The quality assurance of a website depends on automation testing tools that decreased the cost and increases the efficiency. The usability testing tools are used to determine the usability of websites and their effectiveness. The performance of a website can be a critical factor to its success. It depends on the major factor speed. If website speed is fast then performance automatically increases. The performance can be evaluated by using tools which give details of resources and components on that website. There is wide diversity of automated website testing tools are available. The aim of this research paper is to evaluate and compare the automated testing tools to determine their performance, speed, number of requests, load time, page size, SEO (Search Engine Optimization), mobile and security. The performance of different Universities of Punjab is evaluated using automated Usability Testing tools like Pingdom, GTMetrix, Website Grader and Site Speed Checker Tool and results are analysed based on above said parameters.
\end{abstract}

\section{Keywords}

Usability, Web Service, testing, speed, load time, Pingdom tool, GTMetrix tool, Site Speed Checker tool, Website Grader tool

\section{INTRODUCTION}

Usability is single essential factor to measure the quality of web applications. If usability is more then quality of website application is more. Now-a-days, it is recognized as an vital property for the success of Web Applications. The methods used for ensuring usability are one of the most important goals of the Web page research. Usability is currently important by website developers who will develop websites for users. Usability is defined in ISO 9241-11 as "the extent to which a product can be used by specified users to achieve specified context of use" [1]. The theory of usability can be defined as "how well and how easily a user, without formal training, can interact with an information system of a website"[2]. By using different evaluation methods, different outcome may be obtained for the usability of identical domain system. In this paper, authors are considering the web pages of university websites. The university websites are primarily concerned with the Information they need. Information can be syllabus, fee structure, faculty details, Examination form or their results, etc. The questions for every website are how much website should be more usable than others? Each and every websites i.e. company websites, shopping websites, corporate sites, portal sites and hotel sites are different than University websites. For every website, font size, font color, font face, images and content are important considerations. Usability is how simple an Object is to use. The object can be a machine, tool, process, software application or website. Everything that a person can interact with should be usable.

In the case of websites and software applications, usability has been defined as the ease at which an average person can use the software or website to achieve specific goals [3]. Usability is a combination of navigation, memorability, efficiency, learnability, readability, satisfaction and errors. Navigation is how user can easily move in website. Memorability is how users can easy remember the steps to accomplish task on website. Learnability is how easy it is for a new user to accomplish tasks the first time they visit the website. Efficiency is how quickly users can complete tasks on the website after they are familiar with its use. Satisfaction is whether users enjoy the design of the site or satisfy with the website and errors refers to the number of errors users make when they use the site, the severity of errors and how easy they are to recover them. There are 5 E's of usability- $[4,5]$

- Efficiency

- Engaging

- $\quad$ Easy to use

- Effectiveness

- Error tolerant

The paper is organized as: Section 2 discusses the Related work. The Tools for measuring Usability is discussed in the Section 3. Results and analysis along with the parameters is discussed in Section 4. Section 5 accommodates the conclusion.

\section{RELATED WORK}

Grady, Helen M. [6] discussed the benefits of using paper prototypes to conduct usability testing of a Website for Mercer University's School of Engineering Center for excellence in Engineering Education $\left(\mathrm{CE}^{3}\right)$. This paper also discussed the importance of training technical communicators to be user advocates.

Mustafa et al. [7] evaluated the nine Websites of Jordanian universities by two automatic evaluation tools: HTML Toolbox and Webpage analyzer. The effect of their study showed that the overall usability level of the Websites is satisfactory.

Akoglu [8] presented a case-study of a usability evaluation method for Architectural Websites, and introduce a particular tool for accessing the usability of architectural department websites in the University of Istanbul. The evaluation was 
based on two environments: traditional laboratory and Internet environments.

Atterer [9] discussed an approach for improving automated usability tool during the development of a Website, where the HTML Code Analyzer is apply to each Web page in the Website in order to identify potential problems. Researcher also used an automatic validator to verify usability guidelines, and presented a prototype of a model-based automatic usability validator.

Adepoju et al. [10] presented a study to investigate the usability ofthe federal universities' websites in Nigeria. It checks for conformance with both WCAG 1.0 and WCAG 2.0 using three automated tools.

Anwarul et al. [11] used two online automated tools to evaluate nine universities of websites in Jordan i.e. HTML toolbox and web page analyzer. The result obtained from the evaluation was used to provide suggestions to improve usability of the websites. The outcome from the research indicated that there were some weakness in some part of design, interface and performance of the websites.

Nasser et al. [12] evaluated the usability of a departmental website at University of Bangazi. The questionnaire based method and an online automated tool: HTML tool box, were used for evaluaion. It was reported that an acceptable stage of performance was obtained from the evaluation. Consequently, suggestions were provided based on the finding made.

Junaini et al. [13] used an automated tool named WebQual to evaluated three African countries websites. The final report compare the accessibility quality and the rank of complexity of these African countries government's Web pages. It was revealed that hand coded pages be inclined to have larger number of HTML elements and also presented higher number of accessibility problems. Researchers further recommended ways to repair the most common problems in these pages.

Alexendra et al. [14] investigated the usability and content accessibility of UK e-government websites and see if these two events are correlated. The two automatic evaluation tools used were Bobby and LIFT. Based on the automatic evaluation results, ten selected websites were further evaluated by using heuristics evaluation and cognitive walkthrough. The study also involved the use of assistive technology to assess the accessibility issues. The results show a relatively high compliance with the WCAG and a relatively low usability rating for most UK e-government websites.

Oliha et al. [15] used two automated tools i.e. HTML toolbox and webpage analyzer, to evaluate the usability of websites of two Polytechnics in Nigeria. The outcome show that there were some weakness in the phase of design and interface. However, it was concluded that the overall usability level of the studied websites are acceptable.

From the literature study, valuation of websites can be done by using special methods. It could be assessment based through the use of expert; test based, through the use of user or tool based through the use of automated tools. Tool-based automated evaluation uses an automated tool to determine internal (or underlying) attributes of the website. Properties such as the number of HTML page sizes, the sizes of images, HTML files, the number of broken or bad links, browser compatibility, download time, mobile friendliness, page rank and other technical deficiencies within the web pages are discovered through these tools [16], [17]. The most important aim of the evaluation is to ensure quality [15]. The major factor to evaluate a website is Performance, that is why this factor is chosen to evaluate the universities website.

\section{TOOLS FOR MEASURING WEB USABILITY}

The major reason that usability is significant because there are so many similar websites that people will go to the next site if the first one, they visited, is not usable. People will leave website immediately if they are unable to find out how to navigate your site quickly. Usability testing is a technique used to evaluate a product(a website) by testing is on users. There are plenty of tools around which allow website owners and visitors to conduct tests on website [19]Google Website Optimizer, Userfly, Clickdensity, User Plus,Chalkmark, 4Q, CrazyEgg, Loop11, ClickTale, Feedback Army, Silverback, Website Optimizer,OpenHallway, Usabilla, Concept Feedback, Userfly, ClickHeat, Website Grader, Pingdom, GTMetrix, PageSpeed Insight, Qualidator, SiteAnalyzer, ChalkMark, WebPage Analyzer.

From Table 1 which shows the comparison of 21 tools w.r.t. performance, speed, number of requests, load time, page size, user experience, mobile, navigation, design, content, SEO, Security, Heat maps, Click Stream and Accessibility.

\subsection{Tools for Measuring the Performance of Websites}

The automated Usability Testing tools are used for testing the performance of website. Performance is based on several factors i.e. bandwidth, response time, load time and page size. The four tools are selected w.r.t. common parameters from Table 1. From these tool, the common parameters Performance, Speed, No. of Requests, Load time and Page size are selected. Pingdom, GTMetrix, Qualidator, Website Grader, Page Speed Insight, Site Analyzer, WebPage Analyzer tools evaluated the website based on performance. The Comparison of these tools is stated in Table 2:

Table 2. Tools for measuring common parameters

\begin{tabular}{|l|c|c|r|r|r|}
\hline $\begin{array}{c}\text { Tools/Paramet } \\
\text { ers }\end{array}$ & $\begin{array}{c}\text { Perform } \\
\text { ance }\end{array}$ & $\begin{array}{c}\text { No. of } \\
\text { Requests }\end{array}$ & Speed & $\begin{array}{c}\text { Load } \\
\text { Time }\end{array}$ & \multicolumn{1}{c|}{$\begin{array}{c}\text { Page } \\
\text { Size }\end{array}$} \\
\hline Pingdom & $\checkmark$ & $\checkmark$ & & $\checkmark$ & $\checkmark$ \\
\hline GTMetrix & $\checkmark$ & $\checkmark$ & $\checkmark$ & $\checkmark$ & $\checkmark$ \\
\hline Website Grader & $\checkmark$ & $\checkmark$ & & $\checkmark$ & $\checkmark$ \\
\hline $\begin{array}{l}\text { Site Speed } \\
\text { checker }\end{array}$ & $\checkmark$ & $\checkmark$ & $\checkmark$ & $\checkmark$ & $\checkmark$ \\
\hline
\end{tabular}


Table 1. Comparitive Analysis of Automated Usability Testing Tools

\begin{tabular}{|c|c|c|c|c|c|c|c|c|c|c|c|c|c|c|c|}
\hline $\begin{array}{c}\text { Tools } \backslash \\
\text { Param } \\
\text { eter }\end{array}$ & $\begin{array}{l}\text { Perform } \\
\text { ance }\end{array}$ & $\begin{array}{c}\text { No. } \\
\text { of } \\
\text { Requ } \\
\text { ests }\end{array}$ & $\begin{array}{c}\text { Lo } \\
\text { ad } \\
\text { tim } \\
\text { e }\end{array}$ & $\begin{array}{c}\text { Pa } \\
\text { ge } \\
\text { siz } \\
\text { e }\end{array}$ & $\begin{array}{l}\text { User } \\
\text { Exp } \\
\text { erie } \\
\text { nce/ } \\
\text { Inte } \\
\text { racti } \\
\text { on }\end{array}$ & $\begin{array}{l}\text { Mob } \\
\text { ile }\end{array}$ & $\begin{array}{c}\text { Navi } \\
\text { gatio } \\
\mathbf{n}\end{array}$ & $\begin{array}{c}\text { Spee } \\
\text { d }\end{array}$ & $\begin{array}{c}\text { Desig } \\
\text { n }\end{array}$ & $\begin{array}{l}\text { Cont } \\
\text { ent }\end{array}$ & $\begin{array}{c}\text { SE } \\
\text { O }\end{array}$ & $\begin{array}{l}\text { Secu } \\
\text { rity }\end{array}$ & $\begin{array}{c}\text { He } \\
\text { at } \\
\text { Ma } \\
\text { ps }\end{array}$ & $\begin{array}{c}\text { Click } \\
\text { Strea } \\
\text { m } \\
\text { Anal } \\
\text { ysis }\end{array}$ & $\begin{array}{c}\text { Accessib } \\
\text { ility }\end{array}$ \\
\hline $\begin{array}{c}\text { Websit } \\
\mathrm{e} \\
\text { Grader }\end{array}$ & $\checkmark$ & $\checkmark$ & $\checkmark$ & $\checkmark$ & & $\checkmark$ & & & & & $\checkmark$ & $\checkmark$ & & & \\
\hline $\begin{array}{c}\text { Site } \\
\text { Analyz } \\
\text { er }\end{array}$ & $\checkmark$ & & & $\checkmark$ & & & & $\checkmark$ & $\checkmark$ & $\checkmark$ & & & & & $\checkmark$ \\
\hline $\begin{array}{l}\text { Qualida } \\
\text { tor }\end{array}$ & $\checkmark$ & & & & & & & & & & $\checkmark$ & & & & $\checkmark$ \\
\hline $\begin{array}{c}\text { SEO } \\
\text { WebPa } \\
\text { ge } \\
\text { Analyz } \\
\text { er } \\
\end{array}$ & $\checkmark$ & & & & & & & $\checkmark$ & $\checkmark$ & $\checkmark$ & $\checkmark$ & & & & $\checkmark$ \\
\hline $\begin{array}{c}\text { Pingdo } \\
\mathrm{m}\end{array}$ & $\checkmark$ & $\checkmark$ & $\checkmark$ & $\checkmark$ & & & & & & & & & & & \\
\hline $\begin{array}{c}\text { GTmetr } \\
\text { ix }\end{array}$ & $\checkmark$ & $\checkmark$ & $\checkmark$ & $\checkmark$ & & & & & & & & & & & \\
\hline $\begin{array}{c}\text { PageSp } \\
\text { eed } \\
\text { Insight }\end{array}$ & & & & & $\checkmark$ & & & $\checkmark$ & & & & & & & \\
\hline $\begin{array}{c}\text { Site } \\
\text { Speed } \\
\text { Checke } \\
\text { r }\end{array}$ & $\checkmark$ & $\checkmark$ & $\checkmark$ & $\checkmark$ & & & & $\checkmark$ & & & & & & & \\
\hline Loop11 & & & & & & & $\checkmark$ & & & & & & $\checkmark$ & & \\
\hline $\begin{array}{c}\text { CrazyE } \\
\text { gg }\end{array}$ & & & & & $\checkmark$ & & & & & & & & $\checkmark$ & $\checkmark$ & \\
\hline $\begin{array}{l}\text { Webpa } \\
\text { ge Test }\end{array}$ & & $\checkmark$ & $\checkmark$ & $\checkmark$ & & & & & & & & & & & \\
\hline $\begin{array}{c}\text { ClickH } \\
\text { eat }\end{array}$ & & & & & & & & & & & & & $\checkmark$ & $\checkmark$ & \\
\hline $\begin{array}{c}\text { Feedba } \\
\text { ck } \\
\text { Army }\end{array}$ & & & & & $\checkmark$ & & & & & & & & & & \\
\hline $\begin{array}{c}\text { SilverB } \\
\text { ack }\end{array}$ & & & & & & & & & & & & & & $\checkmark$ & \\
\hline Userfly & & & & & $\checkmark$ & & & & & & & & $\checkmark$ & $\checkmark$ & \\
\hline $\begin{array}{c}\text { Usabill } \\
\mathrm{a}\end{array}$ & & & & & $\checkmark$ & & & & & & & & & & \\
\hline $\begin{array}{c}\text { Clickde } \\
\text { nsity }\end{array}$ & & & & & & & & $\checkmark$ & $\checkmark$ & & & & & & \\
\hline $4 Q$ & & & & & $\checkmark$ & & & & & & & & & & \\
\hline $\begin{array}{c}\text { ClickT } \\
\text { ale }\end{array}$ & & & & & $\checkmark$ & $\checkmark$ & & & & & & & $\checkmark$ & & \\
\hline $\begin{array}{c}\text { Web } \\
\text { Page } \\
\text { Analyz } \\
\text { er }\end{array}$ & $\checkmark$ & $\checkmark$ & $\checkmark$ & $\checkmark$ & & & & & & & & & & & \\
\hline $\begin{array}{l}\text { Chalk } \\
\text { Mark }\end{array}$ & & & & & & & & & & & & & $\checkmark$ & $\checkmark$ & \\
\hline
\end{tabular}




\subsubsection{Pingdom:}

Pingdom is fundamentally a monitoring service which keeps the tab on a server, a network and the website as well. The website speed testing tool by Pingdom operates online and is available for free Another valid report which Pingdom tools brings is reports regarding the page analysis, which offers information the time it takes the website to load, the page size and other requests. The Pingdom tool analyzes the loading speed of a website and suggests how to make them faster. This tool identifies what is fast in a given web page, slow, too big and what best practices designer are not following. After entering URL of a website, the tool checks the total number of http requests, total loading time of the page and total size. The tool also provides a detailed structure of the components that contribute to the total size of the site [19].

\subsection{GTMetrix:}

GTMetrix is a free tool that grades your website's speed.GTMetrix tool analyzes the page speed score of a website and suggest how to make them faster. After entering the URL of a website, the tool checks the no. of requests, total loading time of page and total page size. So this tool provides detailed structure of the components that contribute to the total size of the site [20].

\subsubsection{Website Grader:}

Website Grader is a free online tool that grades the site against key metrics like performance, mobile readiness, SEO and security. Website Grader is a free online marketing and SEO tool. Website Grader takes into account the website traffic, findability in search engines, the blogosphere, social media and other inbound marketing factors [21][22]. This tool can easily find out how good your website is? Website Grader tool analyzes the website against the key metrics like Performance, Mobile, SEO, Security and Overall.

\subsubsection{Site Speed Checker:}

Site Speed Checker shows the duration of a given site. This value can be used for viewing how long a site takes to load [23].

\section{EVALUATION USING AUTOMATED TOOLS}

For the evaluation of websites listed in Table 1, Automated Website Evaluation tools are used.

Table 3. List of University Website with URL

\begin{tabular}{|c|c|c|c|}
\hline $\begin{array}{l}\text { University } \\
\text { Website }\end{array}$ & $\begin{array}{l}\text { Educational Sites of } \\
\text { Punjab }\end{array}$ & URL of website & $\begin{array}{l}\text { University } \\
\text { Symbol }\end{array}$ \\
\hline \multirow[t]{5}{*}{$\begin{array}{l}\text { State } \\
\text { Universities }\end{array}$} & $\begin{array}{l}\text { Guru Nanak Dev } \\
\text { University, Amritsar }\end{array}$ & http://gndu.ac.in/ & U1 \\
\hline & $\begin{array}{l}\text { I.K. Gujral Punjab } \\
\text { Technical University, } \\
\text { Kapurthala }\end{array}$ & http://ptu.ac.in/ & $\mathrm{U} 2$ \\
\hline & $\begin{array}{l}\text { Punjab University, } \\
\text { Chandigarh }\end{array}$ & http://puchd.ac.in & U3 \\
\hline & $\begin{array}{l}\text { Punjabi University, } \\
\text { Patiala }\end{array}$ & $\begin{array}{l}\text { www.punjabiunive } \\
\text { rsity.ac.in }\end{array}$ & U4 \\
\hline & DAV University, & www.davuniversity & U5 \\
\hline
\end{tabular}

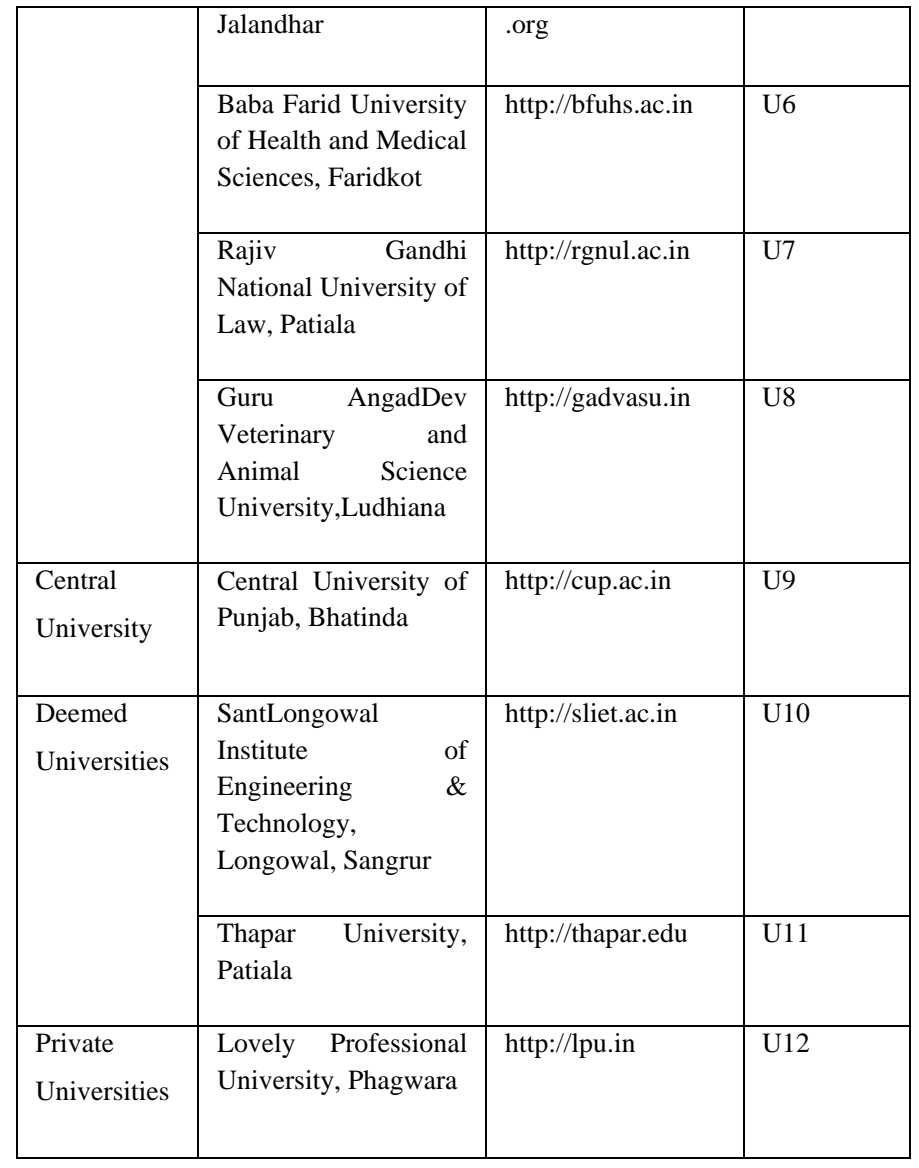

\subsection{Result of Website Performance by Pingdom, GTMetrix, Website Grader and Site Speed Checker Tool}

Pingdom tool and GTMetrix tool evaluates the websitebased on the factors like page load time, performance grade, no. of requests and page size.

Table 4. Performance measured by Pingdom, GTMetrix, Website Grader and Site Speed Checker Tools

\begin{tabular}{|c|c|c|c|c|}
\hline & \multicolumn{4}{|c|}{ Performance (Website Speed) } \\
\hline $\begin{array}{c}\text { University } \\
\text { Symbol }\end{array}$ & $\begin{array}{c}\text { Pingdom } \\
\text { Tool }\end{array}$ & GTMetrix & $\begin{array}{c}\text { Website } \\
\text { Grader }\end{array}$ & $\begin{array}{c}\text { Site } \\
\text { Speed } \\
\text { Check } \\
\text { er Tool }\end{array}$ \\
\hline U1 & $77 \%$ & $45 \%$ & $63 \%$ & $38 \%$ \\
\hline U2 & $80 \%$ & $87 \%$ & $37 \%$ & $58 \%$ \\
\hline U3 & $85 \%$ & $75 \%$ & $83 \%$ & $89 \%$ \\
\hline U4 & $78 \%$ & $75 \%$ & $37 \%$ & $49 \%$ \\
\hline U5 & $79 \%$ & $91 \%$ & $81 \%$ & $66 \%$ \\
\hline U6 & $83 \%$ & $62 \%$ & $90 \%$ & $78 \%$ \\
\hline U7 & $76 \%$ & $57 \%$ & $23 \%$ & $0 \%$ \\
\hline U8 & $81 \%$ & $61 \%$ & $57 \%$ & $43 \%$ \\
\hline U9 & $81 \%$ & $68 \%$ & $30 \%$ & $46 \%$ \\
\hline U10 & $80 \%$ & $83 \%$ & $40 \%$ & $57 \%$ \\
\hline U11 & $74 \%$ & $68 \%$ & $50 \%$ & $42 \%$ \\
\hline U12 & $85 \%$ & $69 \%$ & $70 \%$ & $36 \%$ \\
\hline
\end{tabular}

Website Grader grades the site against the key factors like performance, mobile, SEO and Security and Site Speed checker tool measures the site against the factors like speed, response time, page size and load time. 
The following graph shows the graphical representation of performance measured by Pingdom, GTMetrix, Website Grader and Site Speed checker tool

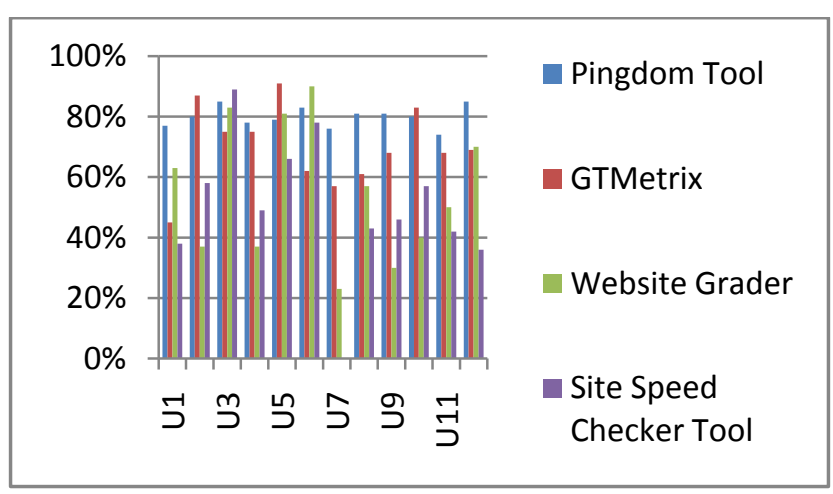

Figure 1. Graphical representation of Table 4

From Figure 1, the results of Pingdom tool measure U3 and U12 websites gives best in performance i.e.85\%. GTMetrix tool evaluates the website U5 as best in performance than other sites i.e.91\%. Website Grader tool evaluates U6 favor website among others i.e.90\% and Site Speed Checker tool gives U3 website with maximum percentage of page loading speed i.e. $89 \%$.

\subsection{Results And Discussion}

This paper is focussed on four automated evaluation tool that are used to calculate the website performance. After evaluating all websites by these four tools, the saved results are stored in Table 4, Table 5, Table 6, Table 7 and Table 8

\subsubsection{Pingdom Tool}

Table 5. Results of Pingdom Tool

\begin{tabular}{|c|c|c|c|c|}
\hline $\begin{array}{c}\text { University } \\
\text { Symbol }\end{array}$ & $\begin{array}{c}\text { Performance } \\
\text { Grade }\end{array}$ & $\begin{array}{c}\text { Requ } \\
\text { ests }\end{array}$ & $\begin{array}{c}\text { Load } \\
\text { Time }\end{array}$ & $\begin{array}{c}\text { Page } \\
\text { Size }\end{array}$ \\
\hline U1 & $77 \%$ & 40 & $1.64 \mathrm{~s}$ & $1.8 \mathrm{mb}$ \\
\hline U2 & $80 \%$ & 36 & $5.33 \mathrm{~s}$ & $1.8 \mathrm{mb}$ \\
\hline U3 & $85 \%$ & 17 & $3.55 \mathrm{~s}$ & $595.7 \mathrm{~kb}$ \\
\hline U4 & $78 \%$ & 78 & $10.47 \mathrm{~s}$ & $2.0 \mathrm{mb}$ \\
\hline U5 & $79 \%$ & 83 & $1.26 \mathrm{~s}$ & $16.1 \mathrm{mb}$ \\
\hline U6 & $83 \%$ & 11 & $840 \mathrm{~ms}$ & $173.7 \mathrm{~kb}$ \\
\hline U7 & $76 \%$ & 111 & $10.55 \mathrm{~s}$ & $11.8 \mathrm{mb}$ \\
\hline U8 & $81 \%$ & 90 & $1.17 \mathrm{~s}$ & $2.3 \mathrm{mb}$ \\
\hline U9 & $81 \%$ & 42 & $14.17 \mathrm{~s}$ & $10.7 \mathrm{mb}$ \\
\hline U10 & $80 \%$ & 27 & $10.79 \mathrm{~s}$ & $11.0 \mathrm{mb}$ \\
\hline U11 & $74 \%$ & 53 & $3.39 \mathrm{~s}$ & $1.3 \mathrm{mb}$ \\
\hline U12 & $85 \%$ & 124 & $19.21 \mathrm{~s}$ & $9.1 \mathrm{mb}$ \\
\hline
\end{tabular}

\subsubsection{GTMetrix Tool}

The GTMetrix tool evaluate the result w.r.t Page speed score, no. of requests, Load time and page size. The performance of website depends on page speed. If page speed is more than performance will automatically increases.

Table 6. Results of GTMetrix Tools

\begin{tabular}{|c|c|c|c|c|}
\hline $\begin{array}{l}\text { University } \\
\text { Symbol }\end{array}$ & $\begin{array}{l}\text { Page } \\
\text { Speed } \\
\text { Score }\end{array}$ & Requests & $\begin{array}{l}\text { Load } \\
\text { Time }\end{array}$ & $\begin{array}{l}\text { Page } \\
\text { Size }\end{array}$ \\
\hline U1 & $45 \%$ & 39 & $1.2 \mathrm{~s}$ & $1.75 \mathrm{mb}$ \\
\hline U2 & $87 \%$ & 36 & $6.7 \mathrm{~s}$ & $1.79 \mathrm{mb}$ \\
\hline U3 & $75 \%$ & 15 & $3.3 \mathrm{~s}$ & $138 \mathrm{~kb}$ \\
\hline
\end{tabular}

\begin{tabular}{|c|c|c|c|c|}
\hline $\mathrm{U} 4$ & $75 \%$ & 77 & $8.5 \mathrm{~s}$ & $2.01 \mathrm{mb}$ \\
\hline $\mathrm{U} 5$ & $91 \%$ & 85 & $9.3 \mathrm{~s}$ & $2.26 \mathrm{mb}$ \\
\hline $\mathrm{U} 6$ & $62 \%$ & 11 & $1.4 \mathrm{~s}$ & $171 \mathrm{~kb}$ \\
\hline $\mathrm{U} 7$ & $57 \%$ & 111 & $10.1 \mathrm{~s}$ & $11.2 \mathrm{mb}$ \\
\hline $\mathrm{U} 8$ & $61 \%$ & 90 & $4.3 \mathrm{~s}$ & $2.25 \mathrm{mb}$ \\
\hline $\mathrm{U} 9$ & $68 \%$ & 42 & $12.1 \mathrm{~s}$ & $10.7 \mathrm{mb}$ \\
\hline $\mathrm{U} 10$ & $83 \%$ & 22 & $6.4 \mathrm{~s}$ & $3.48 \mathrm{mb}$ \\
\hline $\mathrm{U} 11$ & $68 \%$ & 51 & $4.9 \mathrm{~s}$ & $1.27 \mathrm{mb}$ \\
\hline $\mathrm{U} 12$ & $69 \%$ & 125 & $49.1 \mathrm{~s}$ & $8.65 \mathrm{mb}$ \\
\hline
\end{tabular}

\subsubsection{Site Speed Checker}

The PageSpeed tool analyze and optimize the site performance. A good metric for measuring the technical performance of a site is Site speed checker tool. It takes multiple factor into account: Response time, Page size, Load time and Speed.

Table 7. Results of Page Speed Insight Tool

\begin{tabular}{|c|c|c|c|c|}
\hline $\begin{array}{c}\text { University } \\
\text { Symbol }\end{array}$ & Speed & $\begin{array}{c}\text { Response } \\
\text { Time (ms) }\end{array}$ & $\begin{array}{c}\text { Page } \\
\text { size } \\
\text { (sec) }\end{array}$ & $\begin{array}{c}\text { Load } \\
\text { Time } \\
\text { (sec) }\end{array}$ \\
\hline U1 & 127 & 73 & 46.99 & 0.37 \\
\hline U2 & 10.81 & 223 & 110.79 & 10.81 \\
\hline U3 & 18.34 & 1058 & 28.42 & 1.55 \\
\hline U4 & 4.58 & 1250 & 2.75 & 1.55 \\
\hline U5 & 30.57 & 295 & 36.07 & 1.18 \\
\hline U6 & 231.73 & 84 & 25.49 & 0.11 \\
\hline U7 & 33.7 & 362 & 90.66 & 2.69 \\
\hline U8 & 198.71 & 221 & 81.47 & 0.41 \\
\hline U9 & 6.47 & 1526 & 3.75 & 0.58 \\
\hline U10 & 19.71 & 922 & 43.57 & 2.21 \\
\hline U11 & 24.48 & 409 & 86.66 & 3.54 \\
\hline U12 & 816.07 & 43 & 114.25 & 0.14 \\
\hline
\end{tabular}

\subsubsection{Website Grader}

The result of website grader is shown in Table 8. This tool measured against the key metrics like performance, mobile, SEO, security and overall. Website grader also provides the overall result by combining the different parameters.

Table 8. Results of Website Grader Tool

\begin{tabular}{|c|c|c|c|c|c|}
\hline $\begin{array}{l}\text { Universi } \\
\text { ty } \\
\text { Symbol }\end{array}$ & $\begin{array}{l}\text { Performan } \\
\text { ce }\end{array}$ & Mobile & SEO & $\begin{array}{l}\text { Securi } \\
\text { ty }\end{array}$ & $\begin{array}{l}\text { Over } \\
\text { all }\end{array}$ \\
\hline U1 & $19 / 30$ & $15 / 30$ & $15 / 30$ & $0 / 10$ & 49 \\
\hline U2 & $11 / 30$ & $0 / 30$ & $10 / 30$ & $10 / 10$ & 31 \\
\hline U3 & $25 / 30$ & $15 / 30$ & $5 / 30$ & $0 / 10$ & 45 \\
\hline $\mathrm{U} 4$ & $11 / 30$ & $30 / 30$ & $30 / 30$ & $10 / 10$ & 81 \\
\hline U5 & $10 / 30$ & $30 / 30$ & $20 / 30$ & $0 / 10$ & 60 \\
\hline U6 & $27 / 30$ & $0 / 30$ & $10 / 30$ & $0 / 10$ & 37 \\
\hline U7 & $7 / 30$ & $30 / 30$ & $5 / 30$ & $10 / 10$ & 52 \\
\hline U8 & $17 / 30$ & $0 / 30$ & $0 / 30$ & $0 / 10$ & 17 \\
\hline
\end{tabular}




\begin{tabular}{|c|c|c|c|c|c|}
\hline U9 & $9 / 30$ & $0 / 30$ & $10 / 30$ & $0 / 10$ & 19 \\
\hline U10 & $12 / 30$ & $0 / 30$ & $10 / 30$ & $0 / 10$ & 22 \\
\hline U11 & $15 / 30$ & $0 / 30$ & $10 / 30$ & $0 / 10$ & 25 \\
\hline U12 & $24 / 30$ & $15 / 30$ & $20 / 30$ & $10 / 10$ & 69 \\
\hline
\end{tabular}

[3] Galitz, W. O. 2007. The essential guide to user interface design: an introduction to GUI design principles and techniques. John Wiley \& Sons.

[4] Dwivedi, S., \& Dubey, S. K. 2014. Measurement of Web Usability: An Approach. International Journal of Computer and Communication System Engineering (IJCCSE),59-65, ISSN 2312-7694

\section{CONCLUSION}

This paper targets to evaluate various elements required for optimizing the web performance. In this paper focused methodology has been made to find all possible parameters in the website design with reference to some of the major Universities in Punjab. This paper evaluated the university websites of Punjab using four automated tools and gives the comparative results of various factors using these tools. Authors concluded the results in Table 9 which gives the maximum score of university websites against the given factors measured by the Pingdom, GTMetrix, Website Grader and Site Speed Checker tools.

Table 9. Analysis of University websites

\begin{tabular}{|l|c|c|c|c|}
\hline \multirow{2}{*}{ Factors } & \multicolumn{4}{|c|}{ Tools } \\
\cline { 2 - 5 } & Pingdom & $\begin{array}{c}\text { GT } \\
\text { Metr } \\
\text { ix }\end{array}$ & $\begin{array}{c}\text { Website } \\
\text { Grader }\end{array}$ & $\begin{array}{c}\text { Site } \\
\text { Speed } \\
\text { Checke } \\
\text { r }\end{array}$ \\
\hline Performance & U3,U12 & - & U6 & - \\
\hline Speed & - & U5 & - & U12 \\
\hline $\begin{array}{l}\text { Response } \\
\text { time }\end{array}$ & - & - & - & U12 \\
\hline Requests & U12 & U12 & - & - \\
\hline Load time & U6 & U1 & - & U6 \\
\hline Page Size & U5 & U7 & - & U12 \\
\hline Mobile & - & - & U4,U5,U7 & - \\
\hline SEO & - & - & U4 & - \\
\hline Security & - & - & U2,U4,U7 & - \\
& & & U12 & \\
\hline
\end{tabular}

Automated usability of web performance tools can assist save time and improve the quality of site design using various factors, performance, requests, load time, page size, Userexperience, Mobile, SEO and security. The websites U3, U5, U6, U12 score maximum in performance. U12 site got maximum request by visitors, $\mathrm{U} 6$ and $\mathrm{U} 1$ takes maximum loading time. The page size of U5, U7 and U12 is very large. The mobility applications involved in U4, U5 and U7 site. U4 site gives maximum search engine optimization result and U2,U4,U7 and U12 sites are more secure than others.

\section{REFERENCES}

[1] Abran, A., Khelifi, A., Suryn, W., \& Seffah, A. 2003. Usability meanings and interpretations in ISO standards. Software Quality Journal, 11(4), 325-338.

[2] Benbunan-Fich, R. 2001. Using protocol analysis to evaluate the usability of a commercial website. Information and Management, 39, 151-163.

[5] www.wqusability.com/articles/getting-started.html

[6] Grady, H. M. 2000. Web site design: a case study in usability testing using paper prototypes. In Proceedings of IEEE professional communication society international professional communication conference and Proceedings of the 3th annual ACM international conference on Computer documentation: technology \& teamwork (pp. 39-45).

[7] Mustafa, S. H., \& Al-Zoua'bi, L. F. 2008. Usability of the Academic Websites of Jordan's Universities An Evaluation Study. In Proceedings of the 9th International Arab Conference for Information Technology (pp. 3140).

[8] Islam, A., \& Tsuji, K. 2011. Evaluation of usage of university websites in Bangladesh. DESIDOC Journal of Library \& Information Technology, 31(6).

[9] Atterer, R., Wnuk, M., \& Schmidt, A. 2006. Knowing the user's every move: user activity tracking for website usability evaluation and implicit interaction. In Proceedings of the 15th international conference on World Wide Web (pp. 203-212). ACM.

[10] Adepoju, S. A., \& Shehu, I. S. 2014. Usability evaluation of academic websites using automated tools. In User Science and Engineering (i-USEr), 2014 3rd International Conference on (pp. 36-191).

[11] I. Anwarul \& K Tsuji. 2011. "Evaluation of usage of university websites inBangladesh". DESIDOC Journal of Library \& Information Technology,Vol. 31, No. 6, pp. 469-479.

[12] M. A. Nasser \& M .J. El-Sahli. 2013. "An evaluation of the usability of itfaculty educational portal at University of Benghazi," World Academy of Science, Engineering and Technology Vol 7.

[13] S. N. Junaini. 2001. "Navigation design and usability evaluation of the Malaysianpublic university websites," in Proceedings of the Second National Conference on Cognitive Science CSC, Kuching, Sarawak, Malaysia 31-39.

[14] R. Alexander \& B. Andres. 2011. "Automated usability testing: AnalysingAsia websites,"[Online. Available http://www.arxiv.org/pdf/12http://www.arxiv.org/pdf/12 12.349] (accessed 7 June, 2014).

[15] F. O. Oliha. 2014. "Web portal usability among Nigerian university students:A case study of University of Benin, Nigeria," Nigerian Journal ofTechnology (NIJOTECH), Vol. 33(2).

[16] H. A. Mohd \& N. M. Mohammed. 2010. "Accessibility evaluation of Malaysian e government websites," Journal of e-Government Studies and BestPractices.

[17] K. Sukhpal. 2012. "An automated tool for website evaluation," International Journal of Computer Science and Information Technology.Vol 3(3), 4310-4313. 
[18] http://blog.woorank.com/2013/08/20-awesome-usabilitytesting-tools/ (accessed on 20 March 2015)

[19] www.tools.pingdom.com/fpt/ (accessed on 28 April 2015)

[20] www.gtmetrix.com (accessed on 15 May 2015)

[21] www.websitegrader.com (accessed on 12 May 2015)
[22] Wu, G., \& Wu, Y. 2011. A study of the website performance of Xiamen Star Grade Hotels based on the EMICA model. In Advances in computer science, intelligent system and environment (pp. 407-412). Springer Berlin Heidelberg

[23] http://www.seomastering.com/site-speed-checker.php (accessed on 23 April 2011) 